3. Чубатюк Ю. Протистояти загрозам штучного інтелекту можна, не перешкоджаючи інноваціям, - експерт. URL: https://b.ua/tech/2019/01/ 15/417108_protivostoyat_ugrozam.html (дата звернення: 09.04.2021).

4. Стрельник В. В., Демченко А. М., Мироненко А. О. Правове поєднання права інтелектуальної власності та технології штучного інтелекту. Приватне та публічне право. № 4. 2020. C. 50-53. URL: http://pp-law.in.ua/archive/4_2020/12.pdf (дата звернення: 09.04.2021).

DOI https://doi.org/10.30525/978-9934-26-074-2-20

\title{
ТВОРЧІСТЬ ЯК ЕЛЕМЕНТ АВТОРСЬКОГО ПРАВА
}

\author{
Улітіна О. В. \\ кандидат юридичних наук, \\ вчений секретар \\ Науково-дослідного інституту інтелектуальної власності \\ Національної академії правових наук України \\ м. Київ, Украӥна
}

Творчість $є$ одним 3 найважливіших аспектів життя людини. Творчість можна відшукати в будь-якій діяльності, іiі наявність часто $\epsilon$ обов'язковою для існування тієї чи іншої сфери діяльності людини.

Право на свободу творчості відноситься до особистих немайнових прав, які забезпечують соціальне буття особи. Воно закріплене в ст. 309 Цивільного кодексу України, яка гарантує право будь-якої фізичної особи на свободу літературної, художньої, наукової і технічної творчості, а також на повну свободу вибору сфери, змісту та форми творчості [1]. Тобто відповідно до Цивільного кодексу України для творчості важливою ознакою є можливість вільно обирати в іїі рамках, в тому числі це стосується і способів вираження творчості, методів та прийомів, що використовуються. Право на свободу творчості - це по суті право, яке гарантує можливість самого творчого процесу, або інакше кажучи, творчої діяльності.

Проте в цивільному праві також існує право на результати такої діяльності, оскільки процес і його результат мають в юридичній площині дещо різне значення. Право на результати такої діяльності - це право інтелектуальної власності, про що вказує ст. 418 Цивільного кодексу України. Ця стаття встановлю право особи на результат не лише творчої діяльності, але й інтелектуальної [1]. 
Творчість в цьому ключі безперечно $є$ важливим поняттям для права інтелектуальної власності, проте на законодавчому рівні цей термін не розривається, а на доктринальному - все ще точаться суперечки, оскільки творчість $є$ суб'єктивним та певною мірою оціночним поняттям.

Так чи інакше, законодавство України в сфері авторського права постійно звертається до творчості, як важливого елемента права. Відповідно до Закону України «Про авторське право і суміжні права» автором визнається «фізична особа, яка своєю творчою працею створила твір» [2].

Що ж саме мається на увазі під поняттям творчість, творча діяльність, творча праця? Якщо говорити в контексті побутового використання цих термінів, то зазвичай творчість сприймається як щось незвичайне, створене в особливій авторській манері. В цьому процесі автор намагається виразити якісь свої переживання, думки, емоції, застосовуючи при цьому доступні йому техніки та способи. Також творчістю часто називають створення щось своїми руками - вишивання, малювання, ліпка, розфарбовування. Однак не кожен $з$ цих процесів дійсно буде творчим, так важко говорити про творчість, якщо зроблена точна копія картини, вишивка здійснена точно відповідно до малюнку на канві, а картинка розфарбована відповідно до інструкції. В той же час в побуті всі ці процеси ми назвемо творчістю.

Тому важливо розуміти різницю між творчістю в побутовому розумінні і в правовому полі. Так, з точки зору права «творчу діяльність характеризують дві риси: оригінальність і новизна» [3, с. 7]. Однак обидва ці критерії в царині авторського права мають певні особливості. В першу чергу, ні оригінальність, ні новизна в жодному разі в контексті авторського права не можуть бути абсолютними. Як часто кажуть, в музиці всього сім нот, тому створити щось повністю оригінальне чи зовсім нове майже неможливо. Для авторського права оригінальність та новизна є відносними поняттями, а також мають в якійсь мірі оціночний та суб'єктивний характер.

Так, «твір вважається оригінальним за умови наявності в ньому особистого інтелектуального (творчого) внеску автора» [4, с. 35]. Тобто оригінальність присутня вже тоді, коли автор просто самостійно створив твір. Фактично в такому розумінні оригінальність присутня, якщо твір не $\epsilon$ копією іншого твору.

Новизна в контексті творчості в авторському праві також є досить специфічною категорією, яку від оригінальності відрізняє лише спрямування на особистість самого автора, а не на інших творців. Так, «нове у творчості - це не копіювання свого раніше створеного твору, 
а створення чогось нового, чого раніше не існувало серед здобутків цього автора» [3, с. 8].

Оригінальність і новизна як складові творчості в авторському праві не $\epsilon$ досконалими критеріями, в той же час поняття творчі зусилля, хоча також є оціночним та суб'єктивним, має аспекти, які дозволяють оцінити твір, не лише порівнюючи його з іншими. Так, творчі зусилля - це певна діяльність, в першу чергу інтелектуальна, через яку автор втілює власні задуми, ідеї, концепції для створення певного твору. До творчих зусиль може відноситись будь-яка діяльність, на приклад, навчання в школі мистецтв - це прикладення творчих зусиль для подальшого створення картин. Творчі зусилля - це прагнення автора до створення чогось оригінального і нового, його волевиявлення щодо авторства на твір.

Для різних об'єктів авторського права коло того, що відноситься до творчих зусиль може бути різним. Так, для фотографічних творів ознаками творчих зусиль можуть бути вибір об'єкту зйомки; композиція, тобто розташування об'єктів та предметів на світлині; встановлення певним чином освітлення; ракурс зйомки; вибір матеріалу, на якому буде зафіксовано зображення (цифрове фото, плівка, інше); вибір обладнання, за допомогою якого проводиться зйомка і інше.

Критерії визначення творчості $є$ досить розмитими, проте творчість $€$ важливим елементом авторського права, який фактично вказує на охороноздатність твору. Саме тому важливими є пошуки найбільш ефективного та зручного критерію для визначення творчості для об'єктів авторського права. Поряд з оригінальністю і новизною, в цьому аспекті, доцільно також говорити про творчі зусилля, які і можуть слугувати тим самим критерієм творчості для кожного об'єкта авторського права окремо, що з огляду на їх різноманіття, вбачається досить ефективним.

\section{Література:}

1. Цивільний кодекс України від 16 січня 2003 p. № 435-IV / Верховна Рада України. URL: https://zakon.rada.gov.ua/laws/show/43515\#Tеxt (дата звернення: 12.04.2021).

2. Про авторське право і суміжні права: Закон України від 23.12.1993 № 3792-XII / Верховна Рада України. URL: https://zakon.rada.gov.ua/ laws/show/3792-12\#Техt (дата звернення: 12.04.2021).

3. Штефан А. Феномен творчої діяльності в авторському праві. Теорія і практика інтелектуальної власності. 2018. № 4. С. 5-13.

4. Майданик Л. Поняття оригінальності твору в авторському праві: досвід ЄС, України та інших зарубіжних країн. Підприємництво, господарство і прав. 2018. № 10. С. 32-36 